\title{
Electrophoretic Heterogeneity of Ribosomal Protein AT-L30 among Actinomycete Genera
}

\author{
KOZO OCHI \\ National Food Research Institute, 2-I-2 Kannondai, Tsukuba, Ibaraki 305, Japan
}

\begin{abstract}
The ribosomal proteins from 17 type strains of species belonging to various actinomycete genera were compared by two-dimensional polyacrylamide gel electrophoresis. I detected a striking variability among certain ribosomal proteins (designated AT-L30 proteins) with respect to electrophoretic mobility in the first dimension. In contrast, such variability was not observed among ribosomal L30 proteins from other bacteria, such as Escherichia coli, Bacillus subtilis, Pseudomonas aeruginosa, and Staphylococcus aureus. Although actinomycete AT-L30 proteins from different taxa exhibited considerable heterogeneity in electrophoretic mobility, within each genus the proteins had a specific mobility characteristic. On the basis of this observation, the ribosomal AT-L30 proteins from 11 type strains of species belonging to the mycolic acid-containing genera Nocardia, Rhodococcus, Gordona, and Tsukamurella were analyzed. The relative electrophoretic mobilities of AT-L30 protein preparations from these strains, as determined by two-dimensional gel electrophoresis, revealed that the genera Nocardia, Rhodococcus, Gordona, and Tsukamurella can be sharply separated from each other. My results are consistent with the previously discussed view that each of these genera merits separate genus status.
\end{abstract}

The use of two-dimensional separation of ribosomal proteins for identification and classification purposes has been extended to the family Enterobacteriaceae, the family $\mathrm{Ba}$ cillaceae, and several archaebacteria $(2,5,6)$. In the course of a study of Streptomyces relC mutants, I found recently that several Streptomyces species exhibit considerable electrophoretic variability in their ribosomal protein patterns and proposed that the members of the genus Streptomyces have ribosomal protein patterns that are specific for each taxon $(21,23)$. The practical application of ribosomal protein patterns in Streptomyces taxonomy has also been demonstrated (22). Therefore, the next step was to determine the extent of variability of ribosomal protein patterns among various actinomycete genera; such a determination revealed a striking electrophoretic variability among certain ribosomal proteins (designated AT-L30 proteins). In this paper I describe the potential significance of these observations and raise the possibility that ribosomal protein analysis can be used as a new approach for the classification of actinomycetes.

\section{MATERIALS AND METHODS}

Bacterial strains. The strains used in this study are listed in Tables 1 and 2. Most of these strains were type strains that were obtained from the Japan Collection of Microorganisms, Saitama, Japan, the Institute of Fermentation, Osaka, Japan, and the American Type Culture Collection, Rockville, Md.

Preparation of total ribosomal proteins. The strains were grown to mid-exponential phase under the cultural conditions described below. Strains of Escherichia coli, Bacillus subtilis, Pseudomonas aeruginosa, and Staphylococcus aureus were grown at $37^{\circ} \mathrm{C}$ in bouillon medium. Most of the cultures of actinomycetes were grown at $30^{\circ} \mathrm{C}$ in soluble starch-Polypeptone-yeast extract medium containing $0.1 \%$ $\mathrm{MgSO}_{4}$ as previously described (21); the exceptions were the members of the genus Saccharomonospora, Nocardia brevicatena, Nocardia farcinica, and Microbispora aerata, which were grown at $37^{\circ} \mathrm{C}$. Thermoactinomyces vulgaris was grown at $45^{\circ} \mathrm{C}$ in starch-Polypeptone-yeast extract medium.
Ribosomes and ribosomal proteins were prepared as described previously (21)

Two-dimensional PAGE. Two-dimensional polyacrylamide gel electrophoresis (PAGE) in which the method of Kaltschmidt and Wittmann (14) is used has been described in detail previously (21). The gels were run two to three times for each ribosomal protein sample to confirm the reproducibility of the results.

Determination of amino acid sequence. After two-dimensional PAGE, the spot (containing about $20 \mu \mathrm{g}$ of protein) assigned to protein AT-L30 was cut from each gel. The protein was extracted from the gel by electrophoresis. A sequence analysis of the extracted protein was performed with a model 470A protein sequencer (Applied Biosystems). Details of the sequencing procedures will be given elsewhere.

\section{RESULTS}

Variability of ribosomal proteins. Since there was considerable variability in the ribosomal protein patterns (on twodimensional PAGE gels) within the genus Streptomyces (21), I expected that similar or even more extensive variability would be present among other genera of actinomycetes. This was true for a number of actinomycete strains that were examined by using two-dimensional PAGE. A few examples of the results of this analysis are shown in Fig. 1A through G. Representative gram-positive and gram-negative bacteria $(E$. coli, B. subtilis, Pseudomonas aeruginosa, and Staphylococcus aureus) were also examined as controls. The variability observed among these bacteria was much less than the variability observed among genera of actinomycetes (an example of the protein pattern for $B$. subtilis is shown in Fig. $1 \mathrm{H})$. Extensive similarities have also been observed for $E$. coli and Proteus mirabilis; in these bacteria only three proteins exhibited small variations in electrophoretic mobility (2). Thus, extensive variability in ribosomal protein patterns among different genera or different species appears to be a characteristic that is specific for actinomycetes.

Heterogeneity of AT-L30 proteins. Despite the extensive variability of ribosomal protein patterns within the genus 
TABLE 1. Electrophoretic mobilities of ribosomal AT-L30 (or L30) proteins from the type strains of various actinomycete genera and other representative bacteria

\begin{tabular}{|c|c|c|}
\hline Strain & $\begin{array}{c}\text { Mobility of } \\
\text { AT-L30 } \\
(\mathrm{mm})^{a}\end{array}$ & $\mathbf{R E M}^{b}$ \\
\hline Microtetraspora glauca JCM $3300^{\mathrm{T} c}$ & -3.5 & -5.0 \\
\hline Microbispora aerata IFO $12581^{\mathrm{T}}$ & 4.5 & 6.5 \\
\hline Actinomadura madurae ATCC $19425^{\mathrm{T}}$ & 13.0 & 19.0 \\
\hline Actinoplanes utahensis IFO $13244^{\mathrm{T}}$ & 14.5 & 21.0 \\
\hline Streptosporangium roseum IFO $3776^{\mathrm{T}}$ & 14.5 & 21.0 \\
\hline Nocardiopsis dassonvillei IFO $13908^{\mathrm{T}}$ & 16.5 & 24.0 \\
\hline Streptomyces griseus IFO 13189 & 17.0 & 25.0 \\
\hline Kitasatosporia setae IFO $14216^{\mathrm{T}}$ & 20.0 & 29.0 \\
\hline Micromonospora purpurea IFO $12575^{\mathrm{T}}$ & 20.0 & 29.0 \\
\hline Nocardioides luteus JCM $3334^{\mathrm{T}}$ & 20.0 & 29.0 \\
\hline Streptoverticillium orinoci IFO $13466^{\mathrm{T}}$ & 20.0 & 29.0 \\
\hline Kineosporia aurantiaca $\mathrm{JCM} 3230^{\mathrm{T}}$ & 29.5 & 43.0 \\
\hline Actinopolyspora halophila JCM $3278^{\mathrm{T}}$ & 31.5 & 46.0 \\
\hline Dactyrosporangium aurantiacum IFO $12592^{\mathrm{T}}$ & 31.5 & 46.0 \\
\hline Nocardia asteroides $\mathrm{JCM} 3384^{\mathrm{T}}$ & 40.5 & 59.0 \\
\hline Thermoactinomyces vulgaris JCM $3162^{\mathrm{T}}$ & 45.5 & 66.5 \\
\hline Saccharomonospora caesia JCM $3098^{\mathrm{T}}$ & 66.5 & 97.0 \\
\hline Saccharomonospora glauca JCM $7444^{\mathrm{T}}$ & 67.0 & 98.0 \\
\hline Saccharomonospora viridis JCM $3036^{\mathrm{T}}$ & 68.5 & 100 \\
\hline Staphylococcus aureus 6538P & 49.5 & 72.5 \\
\hline Escherichia coli ATCC $11775^{\mathrm{T}}$ & 50.0 & 73.0 \\
\hline Bacillus subtilis strain 61953 & 51.5 & 75.0 \\
\hline Pseudomonas aeruginosa ATCC $10145^{\mathrm{T}}$ & 52.0 & 76.0 \\
\hline
\end{tabular}

${ }^{a}$ Mobility of the AT-L30 protein in the first dimension. A negative value indicates that the protein moved toward the reverse side (the anode side).

${ }_{b}$ The mobility of protein AT-L30 from Saccharomonospora viridis JCM $3036^{\mathrm{T}}$ was defined as unity $(100)$

$\mathrm{T}=$ type strain.

Streptomyces, a few ribosomal proteins appeared to be highly conserved in the eight Streptomyces species tested (21). One of these conserved proteins is indicated in Fig. 1B (arrow) (ribosomal protein pattern of Streptomyces griseus). When the ribosomal protein patterns were compared, it was immediately evident that this protein corresponded to protein BS-L27 of B. subtilis, which is known to be functionally homologous to protein L30 of E. coli (4). Furthermore, although the $\mathrm{N}$-terminal amino acid sequence of this protein from Streptomyces griseus was determined for only seven $\mathrm{N}$-terminal amino acid residues, it exhibited great similarity to the known sequence of the $E$. coli $\mathrm{L} 30$ protein or, to a lesser extent, to the sequence of the Bacillus stearothermophilus L30 protein (Fig. 2). These results provide strong evidence that this protein is homologous to protein $\mathrm{L} 30$ of $E$. coli. Therefore, this ribosomal protein and the equivalent ribosomal proteins from other actinomycete strains were designated the AT-L30 proteins (Fig. 1, arrows).

Surprisingly, the locations of the AT-L30 proteins on the gels after two-dimensional PAGE varied dramatically in the first dimension, but not in the second dimension (Fig. 1). The distances that the AT-L30 proteins moved in the first dimension in the original slab gels are shown in Table 1 . The AT-L30 protein from Microtetraspora glauca displayed the lowest mobility, and the AT-L30 protein from Saccharomonospora viridis exhibited the greatest mobility. Table 1 also shows the electrophoretic mobility of the AT-L30 protein from each culture relative to the electrophoretic mobility of Saccharomonospora viridis AT-L 30 protein, which exhibited the greatest mobility of all of the actinomycete AT-L30 proteins examined. Relative electrophoretic mobility (REM) defined in this way made it possible to consider the mobility of each AT-L30 protein. The experimental error for AT-L30 mobility, as determined by several gel runs of the same sample from Saccharomonospora viridis, was at most $3 \mathrm{~mm}$ (equivalent to an error of $4 \%$ in REM).

Genus specificity of AT-L30 proteins. In the genus Streptomyces, the REMs determined for 10 different species fell into a narrow range (i.e., from 14.5 to 25.5 ) (Table 2). To determine the variability of REMs within the same species, nine strains of Streptomyces lavendulae, which were isolated and identified in various independent laboratories, were also examined. As shown in Table 2, all of the strains tested except strain 4057 had virtually the same REM (24.0 to 25.0 ) (strain 4057 had previously been determined to be misidentified) (22). In addition to the members of the genus Streptomyces, three species belonging to the genus Saccharomonospora were also examined; the REMs for these species again fell into a narrow range (97.0 to 100). The mobilities of the AT-L30 proteins (and thus the REMs) were not affected by cultural conditions, as demonstrated for Saccharomonospora viridis and Nocardia farcinica; when ribosomal proteins were prepared from cells grown at 30 instead of $37^{\circ} \mathrm{C}$ or in different media, no observable difference was detected in AT-L30 mobility. Thus, the AT-L30 proteins appear to exhibit electrophoretic mobilities that are specific for each genus. In contrast, E. coli, B. subtilis, Pseudomonas aeruginosa and Staphylococcus aureus all exhibited similar REMs (72.5 to 76.0) (Table 1). The L30 proteins from these bacteria exhibited the same mobility not only in the first dimension but also in the second dimension (data not shown). The electrophoretic mobilities of the AT-L30 proteins in the second dimension were compared by examining the comigration of Microtetraspora glauca and Saccharomonospora viridis. Although the REMs of these two species were the most dissimilar, only a slight difference was detected in the mobilities in the second dimension.

TABLE 2. Electrophoretic mobilities of ribosomal AT-L30 proteins from members of the genus Streptomyces

\begin{tabular}{|c|c|c|}
\hline Strain $^{a}$ & $\begin{array}{c}\text { Mobility of } \\
\text { AT-L30 } \\
(\mathbf{m m})^{b}\end{array}$ & $\mathbf{R E M}^{c}$ \\
\hline Streptomyces antibioticus ATCC 14888 & 10.0 & 14.5 \\
\hline Streptomyces coelicolor A3(2) & 10.5 & 15.5 \\
\hline Streptomyces parvulus ATCC $12434^{\mathrm{T}}$ & 11.5 & 17.0 \\
\hline Streptomyces violaceus IFO $13103^{\mathrm{T}}$ & 13.5 & 19.5 \\
\hline Streptomyces avidini IFO $13429^{\mathrm{T}}$ & 16.5 & 24.0 \\
\hline Streptomyces griseoflavus FERM 1805 & 17.0 & 25.0 \\
\hline Streptomyces griseus IFO 13189 & 17.0 & 25.0 \\
\hline Streptomyces venezuelae IFO $13096^{\mathrm{T}}$ & 17.0 & 25.0 \\
\hline Streptomyces hygroscopicus IFO $13472^{\mathrm{T}}$ & 17.5 & 25.5 \\
\hline Streptomyces lavendulae IFO $12789^{\mathrm{T}}$ & 16.5 & 24.0 \\
\hline Streptomyces lavendulae JCM 4057 & 10.5 & 15.5 \\
\hline Streptomyces lavendulae JCM 4263 & 16.5 & 24.0 \\
\hline Streptomyces lavendulae JCM 4283 & 17.0 & 25.0 \\
\hline Streptomyces lavendulae JCM 4328 & 16.5 & 24.0 \\
\hline Streptomyces lavendulae IFO 13709 & 16.5 & 24.0 \\
\hline Streptomyces lavendulae MA406-A-1 & 16.5 & 24.0 \\
\hline $\begin{array}{l}\text { Streptomyces lavendulae subsp. fuscus } \\
\text { JCM } 5025^{\mathrm{T}}\end{array}$ & 16.5 & 24.0 \\
\hline $\begin{array}{l}\text { Streptomyces lavendulae subsp. grasserius } \\
\text { IFO } 13045^{\mathrm{T}}\end{array}$ & 16.5 & 24.0 \\
\hline
\end{tabular}

${ }^{a}$ The sources of the strains have been described previously $(21,22)$

$b$ Mobility of the AT-L30 protein in the first dimension. The data were based on data reported previously $(21,22)$.

c The mobility of protein AT-L30 from Saccharomonospora viridis JCM $3036^{\mathrm{T}}$ was defined as unity $(100)$ 


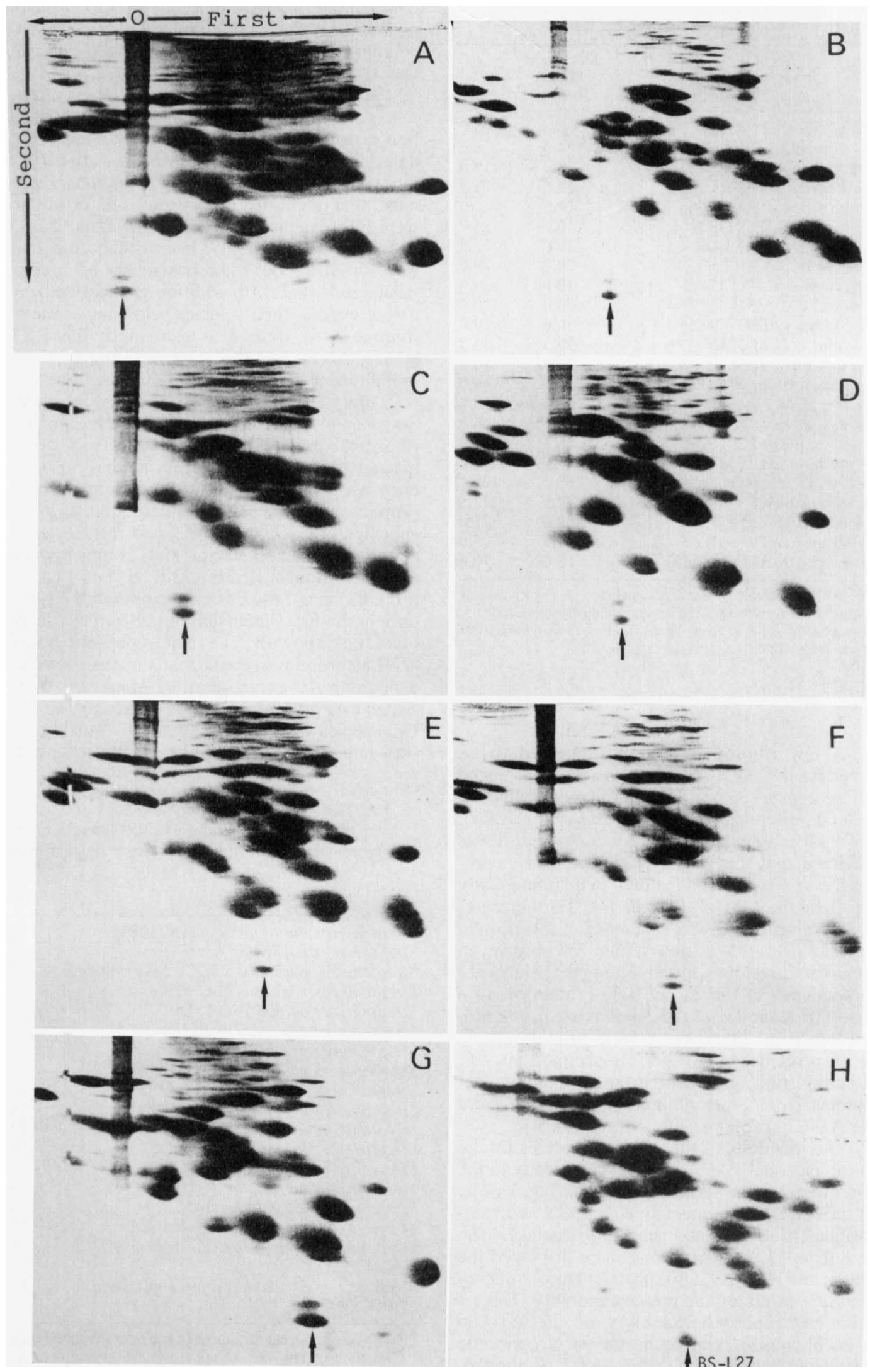


FIG. 1. Two-dimensional PAGE of total ribosomal proteins from actinomycetes. The gel system was based on the system of Kaltschmidt and Wittmann (14). The $O$ in panel A indicates the origin in the first dimension. The arrows indicate the positions of AT-L30 proteins. Strains were arranged in order of protein AT-L30 mobility, with strains having less AT-L30 mobility toward the cathode side. (A) Microtetraspora glauca JCM 3300 ${ }^{\mathrm{T}}$. (B) Streptomyces griseus IFO 13189. (C) Micromonospora purpurea IFO $12575^{\mathrm{T}}$. (D) Nocardioides luteus $\mathrm{JCM} 3334^{\mathrm{T}}$. (E) Nocardia asteroides $\mathrm{JCM} 3384^{\mathrm{T}}$. (F) Thermoactinomyces vulgaris $\mathrm{JCM} 3162^{\mathrm{T}}$. (G) Saccharomonospora viridis $\mathrm{JCM} 3036^{\mathrm{T}}$. (H) B. subtilis 61953.

Taxonomic analysis of the genus Nocardia and related genera. Since the genera of actinomycetes were shown to have REMs that are specific for each genus, it seemed reasonable to utilize this observation in the taxonomy of actinomycetes. To evaluate the efficacy of this approach, an electrophoretic analysis of the AT-L30 proteins was conducted by using species of the genus Nocardia and related genera. All of the organisms examined were type strains (Table 3). The ribosomal proteins of these strains were extracted with acetic acid and separated by two-dimensional PAGE, and then the REM for each AT-L30 protein was determined. It was striking that the members of the genera Nocardia (five species) and Rhodococcus (four species) examined were sharply separated by the electrophoretic properties of the AT-L30 proteins (the REMs were 45.5 to 49.5 for Rhodococcus spp. and 59.0 to $\mathbf{7 0 . 0}$ for Nocardia spp.). Furthermore, although only the type species of the genera Gordona and Tsukamurella were tested, both of these taxa exhibited REMs which were clearly separable from the REMs for the genera Nocardia and Rhodococcus (Table 3 and Fig. 3). Thus, there was a good correlation between the results of the new method and the various criteria currently used to classify actinomycetes. My results could, in turn, be taken as additional evidence that the genera Nocardia, Rhodococcus, Gordona, and Tsukamurella merit separate genus status.

\section{DISCUSSION}

The electrophoretic heterogeneity of AT-L30 proteins among genera of actinomycetes is striking since such heterogeneity has not been detected among bacteria other than actinomycetes. In two-dimensional PAGE, mobility in the first dimension is affected mainly by the net charges of the protein molecules (greater mobility with greater alkalinity). In contrast, mobility in the second dimension is affected mainly by the molecular size of the proteins (greater mobility with smaller size). Therefore, it is evident that the net charges of the AT-L30 proteins differ greatly among the actinomycete genera, apparently from an isoelectric point of 8 to an isoelectric point of more than 12 . Ribosomal proteins have been studied in detail in $E$. coli $(31,33,34)$ and to a lesser extent in the genus Bacillus and archaebacteria (19, 35 ). In $E$. coli, ribosomes consist of three species of RNA $(5 \mathrm{~S}, 16 \mathrm{~S}$, and $23 \mathrm{~S})$ and 53 species of ribosomal proteins. All primary structures of the $E$. coli ribosomal proteins are

$$
\begin{aligned}
& \text { 1) Ala-Arg-Leu----Lys-Ile-Thr-Gln } \\
& \text { 2) Ala-Lys-Thr-Ile-Lys-Ile-Thr-Gln } \\
& \text { 3) Ala-Lys-Lys-Leu-Ala-Ile-Thr-Leu }
\end{aligned}
$$

FIG. 2. Primary structures of the $\mathrm{N}$ termini of the AT-L30 proteins from Streptomyces griseus IFO 13189 (line 1), E. coli K-12 (line 2), and B. stearothermophilus (line 3). The data for E. coli and $B$. stearothermophilus are from references 28 and 15 , respectively. known $(20,34)$. The physicochemical properties of the $E$. coli L30 proteins (32-34) are as follows: molecular weight, 6,411 ; number of amino acid residues, 58 ; isoelectric point, $>12$; tertiary structure, compact, symmetric, and well folded. The complete amino acid sequence is also known; there are 11 basic and 5 acidic amino acids, and there are some sequence similarities with the ribosomal $\mathrm{L} 7 / \mathrm{L} 12$ proteins (28). Although the precise function of the $\mathrm{L} 30$ protein in $E$. coli protein synthesis is still unknown, this protein appears to be located at or near elongation factor $\mathrm{Tu}$ or the guanosine triphosphatase center of the ribosome particle (13, 18 ). Mutational alterations in the $E$. coli $\mathrm{L} 30$ protein render the mutants cold sensitive at $20^{\circ} \mathrm{C}$ and also impair the ribosomal assembly process at this temperature (7). The diverse mobilities of the actinomycete AT-L30 proteins could result from either (i) changes in the primary amino acid sequence, particularly among basic residues, or (ii) different modifications in different taxa. As reported elsewhere, the higher frequency of acidic amino acids and the lower frequency of basic amino acids in the Microtetraspora glauca AT-L30 protein than in the $E$. coli protein may well account for the observed low electrophoretic mobility of the $M i$ crotetraspora glauca AT-L30 protein (24). Thus, it is highly probable that the observed electrophoretic variability of the AT-L30 proteins results from variability in the amino acid sequences per se. On the other hand, in $E$. coli and several species of the family Bacillaceae, the ribosomal proteins are known to be methylated to various degrees; in particular, the L11 protein (or the BS-L11 protein for members of the Bacillaceae) has the highest level of methylation (1). This methylation occurs mainly on lysine residues, resulting in the formation of $\varepsilon-N$-trimethyllysine. Therefore, it is also possible (although less likely) that the electrophoretic vari-

TABLE 3. Electrophoretic mobilities of ribosomal AT-L30

\begin{tabular}{|c|c|c|}
\hline Strain $^{a}$ & $\begin{array}{c}\text { Mobility of } \\
\text { AT-L30 } \\
(\mathrm{mm})^{b}\end{array}$ & REM $^{c}$ \\
\hline Nocardia asteroides JCM $3384^{\mathrm{T}}$ & 40.5 & 59.0 \\
\hline Nocardia otitidiscaviarum JCM $3377^{\mathrm{T}}$ & 42.5 & 62.0 \\
\hline Nocardia amarae JCM $3171^{\mathrm{T}}$ & 45.0 & 65.5 \\
\hline Nocardia farcinica JCM $3088^{\mathrm{T}}$ & 46.0 & 67.0 \\
\hline Nocardia brevicatena JCM $3029^{\mathrm{T}}$ & 48.0 & 70.0 \\
\hline Rhodococcus erythropolis $\mathrm{JCM} 3201^{\mathrm{T}}$ & 31.0 & 45.5 \\
\hline Rhodococcus ruber JCM $3205^{\mathrm{T}}$ & 31.0 & 45.5 \\
\hline Rhodococcus rhodochrous $\mathrm{JCM} 3202^{\mathrm{T}}$ & 32.5 & 47.5 \\
\hline Rhodococcus coprophilus JCM $3200^{\mathrm{T}}$ & 34.0 & 49.5 \\
\hline Gordona bronchialis JCM $3198^{\mathrm{T}}$ & 58.0 & 84.5 \\
\hline Tsukamurella aurantiacus JCM $3226^{\mathrm{T}}$ & 15.0 & 22.0 \\
\hline
\end{tabular}
proteins from the type strains of members of the genera Nocardia, Rhodococcus, Gordona, and Tsukamurella

${ }^{a}$ The nomenclature of the bacteria was based on the proposal of Goodfellow (9).

${ }^{b}$ Mobility of the AT-L30 protein in the first dimension.

c The mobility of protein AT-L30 from Saccharomonospora viridis JCM $3036^{\mathrm{T}}$ was defined as unity (100). 


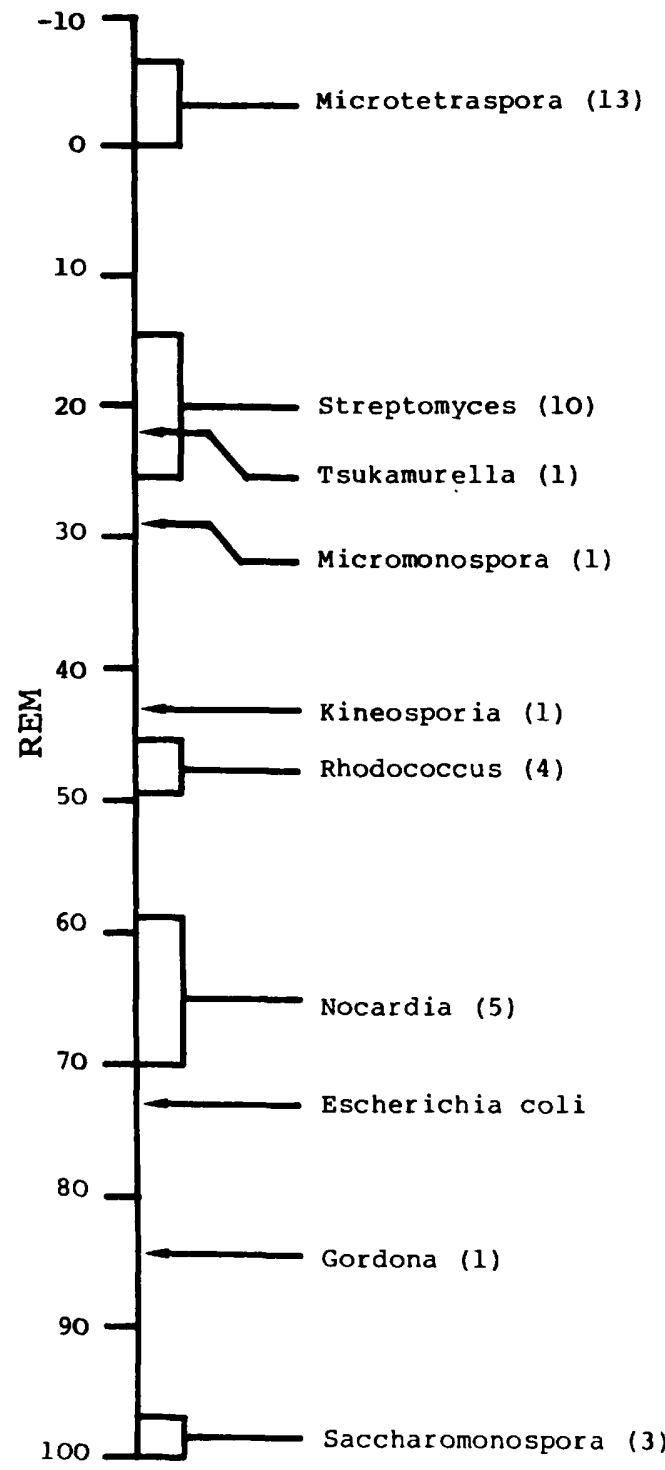

FIG. 3. REM ranges for the genera Nocardia and Rhodococcus and other actinomycete genera. The data are from Tables 1 through 3. The mobility of protein AT-L30 from Saccharomonospora viridis JCM $3036^{\mathrm{T}}$ was defined as unity (100). The numbers in parentheses indicate the number of species examined.

ability among AT-L30 proteins results from the methylation of basic amino acid residues.

Analysis of rRNA sequences is already a well-accepted approach for the study of phylogeny. Similarly, analysis of ribosomal proteins would be an excellent approach for studying the phylogeny of organisms, since variability of ribosomal proteins is more limited than variability of other proteins because of many structural and functional constraints $(12,36)$. Thus, the sequences of a considerable number of ribosomal proteins from the eubacterial, archaebacterial, and eucaryotic kingdoms are related (35). Since the primary structures of the ribosomal proteins are strongly conserved (at least within the archaebacterial kingdom) despite considerable differences at the nucleotide level, Wittmann-Liebold et al. (35) have pointed out that for structural and evolutionary studies of ribosomal proteins, a comparison at the amino acid level is more suitable than a comparison of nucleotide sequences. Indeed, amino acid sequence analysis of AT-L30 proteins, together with measurements of REMs, has already been used successfully to investigate the taxonomic status of several actinomycete genera $(24,25)$.

In addition to amino acid sequence analysis, the ranges of protein REMs have been determined for members of the genera Microtetraspora ( -6.5 to 0$)$, Streptomyces (14.5 to 25.5), Streptosporangium (21.0 to 30.5), Rhodococcus (45.5 to 49.5$)$, Nocardia (59.0 to 70.0), and Saccharomonospora (97.0 to 100) (24-26) (Fig. 3). Thus, the ranges of REMs found in a single genus appear to be about 10 ; an exception is the genus Actinomadura, which exhibited a wide range of protein REMs (14.0 to 41.5) (25). As demonstrated by amino acid sequence analysis of AT-L30 proteins from several actinomycete genera, the REM accurately reflects the net charge of each AT-L30 protein (24). Therefore, it is noteworthy that the Thermoactinomyces vulgaris protein had a REM (66.5) which was close to the REMs for the proteins of other representative bacteria $(72.5$ to 76.0$)$ (Table 1$)$. Until recently, the genus Thermoactinomyces has been considered to be among the oldest actinomycete taxa, because of the characteristic of forming aerial mycelia. However, not only do the 16S rRNA oligonucleotide sequences of these organisms suggest a close relationship with the genus Bacillus, but formation of endospores casts doubts on their status as true actinomycetes (16). Consequently, classification of the genus Thermoactinomyces in the family Bacillaceae has been proposed (30). My results are consistent with this proposal

Microorganisms containing mycolic acids in their cell walls (members of the genera Corynebacterium, Gordona, Mycobacterium, Nocardia, Rhodococcus, and Tsukamurella) have many properties in common $(8,10)$. They all have cell wall chemotype IV and nocardioform morphological features (17). The genus Rhodococcus, one of the nocardioform actinomycetes, has had a long and confused taxonomic pedigree. It is very closely related to the genus Nocardia. Despite the recommendations of many tests for classification (11), the taxonomy of the genus Rhodococcus still remains difficult. In recent investigations Goodfellow et al. (11) have clarified the taxonomy of the redefined genus Rhodococcus by using a battery of numerical classification and rapid enzymic tests. My results support the validity of the redefined genus Rhodococcus since the REM range for the genus Rhodococcus was separated sharply from the REM range for the genus Nocardia (Table 3).

The members of the genera Gordona and Tsukamurella have been previously considered to be rhodococci and are described in the genus Rhodococcus in the latest edition of Bergey's Manual of Systematic Bacteriology (8). However, recent numerical taxonomic and phylogenetic investigations in which rRNA sequencing was used have shown that the genera Gordona and Tsukamurella are taxa equivalent in rank to phena corresponding to the genera Nocardia and Rhodococcus $(3,9,29)$. Consistent with this view is the fact that the REMs observed for Gordona bronchialis and Tsukamurella aurantiacus, the type species of each genus, were clearly separated from the REMs for the genera Rhodococcus and Nocardia. Also, although the genera Gordona and Tsukamurella are very closely related to one another as determined by both chemical and morphological features, these taxa should be considered independent taxa, since the REMs observed for these two taxa were dramatically different (22.0 versus 84.5) (Table 3). 
Members of the genus Nocardioides have the life cycle of nocardioform bacteria and share many properties with members of the genus Nocardia, but have cell wall chemotype I (27). As expected, the results of REM measurements demonstrated clear differentiation of these two taxa (Tables 1 and 3).

As Table 1 shows, the REMs observed for a number of actinomycetes fell into a narrow range (i.e., from 20 to 30 ). As reported elsewhere, similar REM values observed for different genera do not necessarily imply a close relationship of the AT-L30 amino acid sequences, if the taxa compared share few morphological and chemical features (24). Therefore, when the taxonomic relationships among taxa that have REMs in the range from 20 to 30 are studied, a comparison at the level of amino acid sequences will be essential. The novel method described in this paper, together with the results of 16S rRNA oligonucleotide sequencing, would be effective for establishing the phylogenetic status of other equivocally defined actinomycete taxa.

\section{REFERENCES}

1. Amaro, A. M., and C. Jerez. 1984. Methylation of ribosomal proteins in bacteria: evidence of conserved modification of the eubacterial 50S subunit. J. Bacteriol. 158:84-93.

2. Böck, A. 1985. Analysis of ribosomal proteins by two-dimensional gel electrophoresis, p. 109-122. In Methods in Microbiology, vol. 18. Academic Press, Inc., New York.

3. Collins, M. D., J. Smida, M. Dorsch, and E. Stackebrandt. 1988. Tsukamurella gen. nov. harboring Corynebacterium paurometabolum and Rhodococcus aurantiacus. Int. J. Syst. Bacteriol. 38:385-391.

4. Dabbs, E. R. 1983. Mapping of the genes for Bacillus subtilis ribosomal proteins S9, S11, and BL27 by means of antibiotic resistant mutants. Mol. Gen. Genet. 191:295-300.

5. Geisser, M., G. W. Tischendorf, and G. Stöffler. 1973. Comparative immunological and electrophoretic studies on ribosomal proteins of Bacillaceae. Mol. Gen. Genet. 127:129-145.

6. Geisser, M., G. W. Tischendorf, G. Stöffler, and H. G. Wittmann. 1973. Immunological and electrophoretical comparison of ribosomal proteins from eight species belonging to Enterobacteriaceae. Mol. Gen. Genet. 127:111-128.

7. Geyl, D., A. Böck, and H. G. Wittmann. 1977. Cold-sensitive growth of a mutant of Escherichia coli with an altered ribosomal protein S8: analysis of revertants. Mol. Gen. Genet. 152:331336.

8. Goodfellow, M. 1989. Genus Rhodococcus, p. 2362-2371. In S. T. Williams, M. E. Sharpe, and J. G. Holt (ed.), Bergey's manual of systematic bacteriology, vol. 4. The Williams \& Wilkins Co., Baltimore.

9. Goodfellow, M. The family Nocardiaceae. In A. Balows, H. G. Trüper, M. Dworkin, W. Harder, and K. H. Schleifer (ed.), The prokaryotes, 2nd ed., in press. Springer-Verlag, New York.

10. Goodfellow, M., and M. P. Lechevalier. 1989. Genus Nocardia p. 2350-2361. In S. T. Williams, M. E. Sharpe, and J. G. Holt (ed.), Bergey's manual of systematic bacteriology, vol. 4. The Williams \& Wilkins Co., Baltimore.

11. Goodfellow, M., E. G. Thomas, A. C. Ward, and A. L. James. 1990. Classification and identification of rhodococci. Zentralbl. Bakteriol. Parasitenkd. Infektionskr. Hyg. Abt. 1 Orig. 274:299_ 315.

12. Hori, H., B. L. Lim, T. Ohama, T. Kumazaki, and S. Osawa 1985. Evolution of organisms deduced from $5 \mathrm{~S}$ rRNA sequences, p. 324-335. In T. Ohta and K. Aoki (ed.), Population genetics and molecular evolution. Japan Scientific Societies Press/Elsevier, Tokyo.

13. Jose, C. S., C. G. Kurland, and G. Stöffler. 1976. The protein neighborhood of ribosome-bound elongation factor Tu. FEBS Lett. 71:133-137.

14. Kaltschmidt, E., and H. G. Wittmann. 1970. Ribosomal proteins. VII. Two-dimensional polyacrylamide gel electrophoresis for finger-printing of ribosomal proteins. Anal. Biochem. 36: $401-412$.

15. Kimura, M. 1984. Proteins of the Bacillus stearothermophilus ribosome. J. Biol. Chem. 259:1051-1055.

16. Lacey, J., and T. Cross. 1989. Genus Thermoactinomyces Tsiklinsky $1899,501^{\mathrm{AL}}$, p. 2574-2585. In S. T. Williams, M. E. Sharpe, and J. G. Holt (ed.), Bergey's manual of systematic bacteriology, vol. 4. The Williams \& Wilkins Co., Baltimore.

17. Lechevalier, H. A. 1989 . Nocardioform actinomycetes, p. 23482350. In S. T. Williams, M. E. Sharpe, and J. G. Holt (ed.), Bergey's manual of systematic bacteriology, vol. 4. The Williams \& Wilkins Co., Baltimore.

18. Maassen, J. A., and W. Möller. 1974. Identification by photoaffinity labeling of the proteins in Escherichia coli ribosomes involved in elongation factor G-dependent GDP binding. Proc. Natl. Acad. Sci. USA 71:1277-1280.

19. Matheson, A. T., J. Auer, C. Ramirez, and A. Böck. 1990 Structure and evolution of archaebacterial ribosomal proteins, p. 617-635. In W. E. Hill, A. Dahlberg, R. A. Garrett, P. B Moore, D. Schlessinger, and J. R. Warner (ed.), The ribosome: structure, function, and evolution. American Society for Microbiology, Washington, D.C.

20. Noller, H. F., M. Asire, A. Barta, S. Douthwaite, T. Goldstein, R. R. Gutell, D. Moazed, J. Normanly, J. B. Prince, S. Stern, K Triman, S. Turner, B. Van Stolk, V. Wheaton, B. Weiser, and C. R. Woese. 1986. Studies on the structure and function of ribosomal RNA, p. 143-163. In B. Hardesty and G. Kramer (ed.), Structure, function, and genetics of ribosomes. SpringerVerlag, New York.

21. Ochi, K. 1989. Heterogeneity of ribosomal proteins among Streptomyces species and its application to identification. J. Gen. Microbiol. 135:2635-2642.

22. Ochi, K. 1989. Taxonomic characterization of Streptomyces lavendulae by electrophoretic analysis of ribosomal proteins. Actinomycetologica 3:111-114.

23. Ochi, K. 1990. Streptomyces relC mutants with an altered ribosomal protein ST-L11 and genetic analysis of a Streptomyces griseus relC mutant. J. Bacteriol. 172:4008-4016.

24. Ochi, K., and S. Miyadoh. 1992. Polyacrylamide gel electrophoresis analysis of ribosomal protein AT-L30 from an actinomycete genus, Streptosporangium. Int. J. Syst. Bacteriol. 42 $151-155$.

25. Ochi, K., S. Miyadoh, and T. Tamura. 1991. Polyacrylamide gel electrophoresis analysis of ribosomal protein AT-L30 as a novel approach to actinomycete taxonomy: application to the genera Actinomadura and Microtetraspora. Int. J. Syst. Bacteriol. 41:234-239.

26. Ochi, K., and M. Yoshida. 1991. Polyacrylamide gel electrophoresis analysis of mycolateless wall chemotype IV actinomycetes. Int. J. Syst. Bacteriol. 41:402-405.

27. Prauser, H. 1989. Genus Nocardioides, p. 2371-2375. In S. T. Williams, M. E. Sharpe, and J. G. Holt (ed.), Bergey's manual of systematic bacteriology, vol. 4. The Williams \& Wilkins Co., Baltimore.

28. Ritter, E., and B. Wittmann-Liebold. 1975. The primary structure of protein L30 from Escherichia coli ribosomes. FEBS Lett. 60:153-155.

29. Stackebrandt, E., J. Smida, and M. D. Collins. 1988. Evidence of phylogenetic heterogeneity within the genus Rhodococcus: renewal of the genus Gordona (Tsukamurella). J. Gen. Microbiol. 34:341-348.

30. Stackebrandt, E., and C. R. Woese. 1981. Towards a phylogeny of the actinomycetes and related organisms. Curr. Microbiol. 5:197-202.

31. Stöffler-Meilicke, M., and G. Stöffler. 1990. Topography of the ribosomal proteins from Escherichia coli within the intact subunits as determined by immunoelectron microscopy and protein-protein cross-linking, p. 123-133. In W. E. Hill, A. Dahlberg, R. A. Garrett, P. B. Moore, D. Schlessinger, and J. R. Warner (ed.), The ribosome: structure, function, and evolution. American Society for Microbiology, Washington, D.C.

32. Wittmann, H. G. 1982. Components of bacterial ribosomes 
Annu. Rev. Biochem. 51:155-183.

33. Wittmann, H. G. 1986. Structure of ribosomes, p. 1-27. In B. Hardesty and G. Kramer (ed.), Structure, function, and genetics of ribosomes. Springer-Verlag, New York.

34. Wittmann-Liebold, B. 1986. Ribosomal proteins: their structure and evolution, p. 326-361. In B. Hardesty and G. Kramer (ed.), Structure, function, and genetics of ribosomes. Springer-Verlag, New York.

35. Wittmann-Liebold, B., A. K. E. Köpke, E. Arndt, W. Krömer,
T. Hatakeyama, and H. G. Wittmann. 1990. Sequence comparison and evolution of ribosomal proteins and their genes, $\mathrm{p}$. 598-616. In W. E. Hill, A. Dahlberg, R. A. Garrett, P. B. Moore, D. Schlessinger, and J. R. Warner (ed.), The ribosome: structure, function, and evolution. American Society for Microbiology, Washington, D.C.

36. Woese, C. R. 1987. Bacterial evolution. Microbiol. Rev. 51:221271. 